\title{
THE NEXUS BETWEEN TAX REFORMATION, FINANCIAL DEVELOPMENT AND ECONOMIC RECOVERY: THE CASE OF MALAYSIA
}

\author{
Roshaiza TAHA ${ }^{1}$, Jūrate ŠLIOGERIENE ${ }^{2 *}$, Nanthakumar LOGANATHAN ${ }^{3}$, \\ Izolda JOKŠIENE ${ }^{4}$, Muhammad SHAHBAZ ${ }^{5}$, Abbas MARDANI ${ }^{6}$ \\ ${ }^{1}$ School of Maritime Business and Management, Universiti Malaysia Terengganu, Malaysia \\ ${ }^{2}$ Department of Construction Management and Real Estate, \\ Vilnius Gediminas Technical University, Lithuania \\ ${ }^{3}$ Faculty of Management, Universiti Teknologi Malaysia, Malaysia \\ ${ }^{4}$ Department of Business Management, Vilnius Gediminas Technical University, Lithuania \\ ${ }^{5}$ Montpellier Business School, France \\ ${ }^{6}$ Department of Business Administration, Universiti Teknologi Malaysia, Malaysia
}

Received 29 Jun 2017; accepted 14 August 2017

\begin{abstract}
The main purpose of this paper is to establish the plausibility and the dynamic nexus between financial developments, economic growth and tax revenue in Malaysia. The analysis of these relationships is vital considering the instability of the global economy which has affected growth. In this study, we employed annual time series data covering the period of 1970-2015. Using advanced co-integration and causality analysis, we found strong evidence on the relationship between each of the examined variables. The results from this study provide evidence on the taxes-growth nexus for Malaysia. An inverted U-shaped relationship is found between financial development and tax collection, while a U-shape reflects the economic condition. The nexus between economic growth and tax revenue enhances fiscal policies in the creation of transparent and mature financial systems which will further boost the collection of government revenues in Malaysia. The results of this study may provide an avenue for researchers and policymakers to understand the nature of the relationship between the examined variables and further assist in the formulation of new policies for economic sustainability.
\end{abstract}

Keywords: causality, economic growth, economic recovery, financial development, taxation, Malaysia.

JEL Classification: C12, H20.

${ }^{*}$ Corresponding author. E-mail: Jurate.sliogeriene@vgtu.lt 


\section{Introduction}

The Malaysian economy's recovery from the Asian Financial Crisis (AFC) was further obstructed by the Global Financial Crisis (GFC) which was faced by the world economies in 2008. Based on official government statistics, Malaysia's economy is more prone to economic recession but has not been affected by any epidemics or public health emergencies over the last three decades. Ariff and Abu Bakar (1999), for example, argued that the direction of policies in Malaysia such as embarking on expansionary fiscal policies, easing monetary policy, implementing capital controls and fixing the exchange rate are necessary for improved growth prospects. Such steps, they argue, would also help to ensure that the economy remains stable in either strong or weak economic growth environments. Realizing this, the Malaysian government has put in full efforts to promote financial activity, which has further helped to spur economic growth. With the stability of Malaysia's economy, the capital market expanded by $10.5 \%$ to RM2.7 trillion in 2013, underpinned by steady growth in key markets (Treasury Department, 2016). Overall, tax revenues in Malaysia rely on economic sustainability, and a large pool of investors in the market. Looking at the trend of revenue collection over the past 40 years, tax revenue collection has been vulnerable to the economic crisis. Similar to economic growth, the total revenue collection recorded a drop or lower growth during the post-crisis period in 1986, 1998, 2002 and 2009. The trends of economic growth, and financial markets represented by market capitalization and revenues are as per Table 1.

Table 1. Malaysia's financial market, growth and taxation (in RM million) (source: Ministry of Finance Malaysia, 2016)

\begin{tabular}{|l|c|c|c|c|c|c|}
\hline \multirow{2}{*}{} & \multicolumn{2}{|c|}{$1985-1986$} & \multicolumn{2}{c|}{1997 AFC } & \multicolumn{2}{c|}{2008 GFC } \\
\cline { 2 - 7 } & Crisis & Post Crisis & Crisis & Post Crisis & Crisis & Post Crisis \\
\hline Market capitalization & - & - & 7,938 & 3,994 & 10,343 & 9,979 \\
\hline GDP & 78,891 & 72,907 & 281,795 & 283,243 & 769,949 & 712,857 \\
\hline Revenue & 21,115 & 19,518 & 65,736 & 56,710 & 159,793 & 158,639 \\
\hline
\end{tabular}

The pivotal role of financial development and economic sustainability on taxation has been stressed in the earlier research conducted by Levine (1991) using an endogenous growth model. Barro and Sala-I-Martin (1992) and Futagami, Morita, and Shibata (1993), argued for this idea by claiming that tax affects a country's economic development and should be considered in any economic growth model, using an endogenous growth model to discuss this. Generally, in order to understand the nexus between finance-growth-taxation one needs to understand the (i) finance-growth nexus; (ii) growth-taxation nexus; and (iii) finance-taxation nexus. The existing studies on finance-growth nexus provide conflicting results. There is a huge number of studies that strongly support financial stability as necessary to developing the way towards economic sustainability in most developing countries (Uddin, Sjö, \& Shahbaz, 2013; Thumrongvit, Kim, \& Pyun, 2013; Ngare, Nyamongo, \& Misati, 2014). These studies suggest that countries with a better stock market tend to grow faster as compared to countries without stock market stability. Meanwhile, Anwar and Sun (2011) and Menyah, 
Nazlioglu, and Worlde-Rufael (2014) argue that recent financial developments do not have a significant impact on economic growth.

The literature on economic sustainability and taxation is rich and varied. This body of literature dates back to the work of Herfindahl (1957), who studied the uncertainty of tax policy ability to promote economic growth. Adkisson and Mohammed (2014), however, have empirically examined the relationship and support the importance of taxation on economic sustainability. This is due to the fact that, in reality, the frequent changes of tax policy have made studies that utilize time series analysis specifically not feasible. The relationship between the financial system and economic growth has been the subject of thorough theoretical discussion for many years. An abundance of studies utilizing different techniques has also been devoted to empirically examine the link between financial development and economic growth, yet the question of whether financial activities cause economic growth or vice versa remains unresolved (Oskooe, 2010; Hye \& Islam, 2012; P. K. Narayan \& S. Narayan, 2013; Ngare et al., 2014). There are several empirical studies that support the positive relationship, which is finance-led growth. Uddin et al. (2013) suggested that in Kenya, the development of the financial sector has had a positive impact on economic growth in the long-run. Similar results were also reported by Thumrongvit et al. (2013), Agbloyor, Abor, Adjasi, and Yawson (2014) and Ngare et al. (2014) for panel analysis where finance positively led growth. This indicates that financial stability does play a significant role in determining future growth. However, Chen, Wu, \& Wen (2013) claimed that the link only exists in high-income provinces whereas a negative relationship exists in low-income countries.

Many believe that the channel of transmission is from financial development to economic growth. The growth effect of financial development however is sensitive to the choice of proxy selected to represent financial development. Adu, Marbuah, and Mensah (2013) using indexes created from principal component analysis, Hsueh, $\mathrm{Hu}$, and $\mathrm{Tu}$ (2013) utilizing bootstrap panel Granger analysis, and Herwartz and Walle (2014) relying on functional co-efficient modeling concluded that the size and type of financial market do matter in determining the level of the finance-growth relationship. Madsen and Ang (2016) argued that ideas production, savings, fixed investments and schooling as proxies of financial development influence and are conducive to the growth of a country. Narayan and Narayan (2013) supported the negative or weak effect of financial development on economic growth. This is due to the other factors that can be considered in formulating macroeconomic policies which also affect future growth. Menyah et al. (2014) also supported the evidence of a weak relationship between financial development and economic growth by utilizing a financial development index which was developed using principal component analysis. Similar findings were also reported by Adeniyi, Oyinlola, Omisakin, and Egwaikhide (2015) and Zhang and Bezemer (2016) in the case of Nigeria and China, respectively. For Nigeria, although negative results were reported, a sign reversal resulted in accounting for threshold-type effects showing the turning points in the finance-growth association.

Although the role of taxation has always been abandoned in the earlier wave of economic growth models, it is widely recognized in the endogenous growth model. Studies and theories have since been diverted to focus on analyzing the effect of taxation on economic development. Supply-side economics suggest that fiscal policy has a significant effect on the 
economy. Blackburn, Bose, and Capasso (2012) and Radu (2012) argued on the incidence of tax evasion with lower stages of economic development, where this shows the greater size of underground economies. Hatfield (2015) also mentioned that governments will prefer to under-provide public goods which always benefits citizens directly. Zhang, Ru, and Li (2016) postulated that in the endogenous growth model, public spending composition is crucial in determining the optimal tax structure. Focusing on optimal tax structure with an inverted U-shape relationship between taxation and growth, Aghion, Akcigit, Cagé, and Kerr (2016) highlighted that such a relationship can be distorted by corruption. Similar to this is the study by Zhang et al. (2016) which also suggested that the focus should be directed on how public spending is being allocated to achieve the optimal tax structure. Adding to the discussion, Cavallari and Romano (2017) stressed the importance of focusing on the tax and benefits systems as a whole to evaluate the efficiency and equity implications of tax policies which may not crowd out private expenditures and later spur growth. Empirically, results can be classified into negative, positive or no significant relationships (Barro \& Sala-I-Martin, 1992; Futagami et al., 1993). For example, Feenberg and Rosen (1987) and Widmalm (2001) ruled out the existence of a connection between taxation and economic growth and found a statistically insignificant relationship using the average of taxation for OECD countries. Widmalm (2001), for instance, proved that there is no direct theoretical argument for the correlation between a country's average tax rate and economic growth.

Kneller, Bleaney, and Gemmell (1999) identified the impact of distortionary taxes in reducing the growth rate of all countries in the sample. A similar result was found by Lee and Gordon (2005) and Loganathan, Taha, Ahmad, and Subramaniam (2017) in investigating the relationship between these variables, where they found that increases in corporate tax rates led to lower future growth rates within countries while the effect of changes in personal tax were less clear-cut. Therefore, Kneller et al. (1999) and Lee and Gordon (2005) supported the findings from the literature on tax and economic growth as previously discussed. In line with the above discussion, Ojede and Yamarik (2012) and Li and Lin (2015) used panel data analysis and found that property and sales tax rates have negative effects on long-run income growth. In contrast, Yilmaz (2013) believed that there is a probability of a positive effect with an increase in tax under the condition of having a competitive structure in an economy. Adkisson and Mohammed (2014) supported the direction of relationship from taxation to economic growth where utilizing a pooled mean group, the tax structure was shown to a statistical relationship with short-term economic growth. Conversely, Abdullah and Morley (2014), applying standard Granger causality on panel data of OECD countries, suggested some evidence of long-run causality running from economic growth to increased revenue from the environmental taxes.

Meanwhile, Taha, Colombage, Maslyuk, and Loganathan (2013) examined whether tax revenue had a major effect on financial activities in Malaysia and supported the fact that the financial system positively influences the tax revenue collection. Similarly, Jinjarak (2013) and Aizenman and Pasricha (2013) added to the strand of literature which believes that the financial movement of a country does reflect the fiscal policy measures. Exhaustive studies have clearly documented the relationship between financial development and economic activities (Thumrongvit et al., 2013; Menyah et al., 2014; Ngare et al., 2014), financial development 
and taxation (Tagkalakis, 2011; Bhattacharyya \& Holder, 2014) and taxation and economic activities (Ojede \& Yamarik, 2012; Yilmaz, 2013; Abdullah \& Morley, 2014; Adkisson \& Mohammed, 2014; Zimmermannova, Skalickova, \& Siroky, 2016). The recent wave of research discusses the importance of fiscal policy in influencing investment decisions (Schandlbauer, 2016; Hove, Tchana, \& Mama, 2017; Kumar, 2017). However, it is believed that effective and efficient fiscal policy relating to taxation is considered vital for the economic survival of any country, which later stimulates the investment environment (Peter \& Kerr, 2001). RomeroÁvila and Strauch (2008) conducted empirical analysis for European countries over the period of 1960-2001, providing robust evidence that distortionary taxation affects growth in the medium term.

In addition, Soli, Harvey, and Hagan (2008), discussing the relationship between fiscal policy, private investment and economic growth in Ghana, claimed that economic growth is influenced by government expenditures as well as taxes on international trade, while private investment is influenced by other types of tax. Bodman, Campbell, and Le (2012) and Ho and Yang (2013) provided a theoretical argument on how taxation affects economic growth and later influences financial development. Bodman et al. (2012) believe that the effects of taxation and investment on the steady state output level of an economy depends on the government's decision on fiscal policy. Ho and Yang (2013), however, argued that in a small open economy, imposing high capital income tax rates is a growth promoting approach only if the degree of integration with the world capital market is low. Examining the relationship in a panel of 27 European countries, Goulas and Zervoyianni (2013) suggested that a fiscal imbalance would adversely affect economic growth where this leads to the crowding-out of private investments and the distortion of products and financial markets.

Although such relationships have been widely discussed, the literature still lacks a unique empirical relationship due to differences in the sample sizes and levels of economic development of the countries studied, as well as differences in the variables used as proxies for taxation, economic growth and financial markets (Stoilova, 2017). Therefore, there is a need to bridge this gap or, at least, to expand the discussion to other financial instruments such as the stock market in order to provide a broader picture of the relationship between economic growth, taxation and financial systems.

\section{Data and empirical analysis strategies}

The link between taxation-led-growth is the most common issue arising in previous studies, and we included financial development as a potential determinant for taxation. Our study covers the period of 1970-2015 and the relationship between the variables is specified as follows:

$$
\operatorname{Tax}_{t}=f\left(F D_{t}, G D P_{t}, G D P_{t}^{2}\right) .
$$

We converted all series into natural logarithms and the log-linear form of specification is written as:

$$
\begin{aligned}
& \operatorname{Tax}_{t}=\beta_{1}+\beta_{2} F D_{t}+\beta_{3} G D P_{t}+\beta_{4} G D P_{t}^{2}+\mu_{t} \\
& \operatorname{Tax}_{t}=\alpha_{1}+\alpha_{2} G D P_{t}+\alpha_{3} F D_{t}+\alpha_{4} F D_{t}^{2}+v_{t}
\end{aligned}
$$


where, Tax denotes total tax revenues (direct and indirect tax revenues); FD and $\mathrm{FD}^{2}$ are the financial development index, converted by applying the Principal Component Method (PCM). The three principal components are, the banking sector (percentage of the GDP), domestic credit to the private sector (percentage of GDP), and money and quasi money (percentage of the GDP); GDP and GDP ${ }^{2}$ are the real GDP per capita and its square series, respectively; and $\mu_{t}$ and $v_{t}$ are the random error terms. This data was collated from the Treasury Department (2016) and World Development Indicators CD-ROM from the World Bank (2015). To determine the level of integration, we used the Zivot and Andrews (1992) test, also known as the ZA unit root test, which incorporates a single structural break in the data series.

The next was the autoregressive distributed lag model (ARDL) bound testing approach to determine the long-run co-integration proposed by Pesaran, Shin, and Smith (2001). This ARDL approach was preferable in comparison to classical basic co-integration approaches, because it is flexible for series integrated with $I(0)$ or $I(1)$, or mixed $I(0)$ and $I(1)$ integration stages between the series. The second advantage for using the ARDL model was the accurate and consistent co-integration results for small samples (Pesaran et al., 2001). The empirical formulation of the dynamic unrestricted error correction model using the ARDL bounds testing approach can be illustrated as follows:

$$
\begin{gathered}
\Delta \operatorname{Tax}_{t}=\beta_{0}+\beta_{T} T+\sum_{i=1}^{p} \alpha_{1} \Delta \operatorname{Tax}_{t-i}+\sum_{j=0}^{q} \alpha_{2} \Delta F D_{t-j}+\sum_{k=0}^{r} \alpha_{3} \Delta G D P_{t-k}+\sum_{l=0}^{s} \alpha_{4} \Delta G D P_{t-l}^{2}+ \\
\gamma_{1} \operatorname{Tax}_{t-i}+\gamma_{2} F D_{t-i}+\gamma_{3} G D P_{t-i}+\gamma_{4} G D P_{t-i}^{2}+\varepsilon_{1 t} \\
\Delta F D_{t}=\beta_{0}+\beta_{T} T+\sum_{i=1}^{p} \alpha_{1} \Delta F D_{t-i}+\sum_{j=0}^{q} \alpha_{2} \Delta F D_{t-i}^{2}+\sum_{k=0}^{r} \alpha_{3} \Delta G D P_{t-i}+\sum_{l=0}^{s} \alpha_{4} \Delta \operatorname{Tax} x_{t-i}+ \\
\gamma_{1} G D P_{t-i}+\gamma_{2} F D_{t-i}+\gamma_{3} F D_{t-i}^{2}+\gamma_{4} \operatorname{Tax}_{t-i}+\varepsilon_{2 t},
\end{gathered}
$$

where, $\Delta$ is the difference operator and $\varepsilon_{t}$ is the residual term. In the case of choosing the lag length, we used the Akaike Information Criterion (AIC) because it has lower prediction error compared to other lag selection criteria. The null hypothesis of no long-run relationship between the variables is $H_{0}: \gamma_{1}=\gamma_{2}=\gamma_{3}=\gamma_{4}=0$ against $H_{1}: \gamma_{1}=\gamma_{2}=\gamma=\gamma_{4} \neq 0$. To decide whether the variables are co-integrated in the long-run or not, we used Pesaran et al. (2001)'s lower and upper critical bounds. To examine the interrelated co-integration between the variables, we calculated the $F$-statistics by applying the following models: $F_{\text {Tax }}(\operatorname{Tax} \mid F D$, $\left.G D P, G D P^{2}\right)$ and $F_{T a x}\left(\operatorname{Tax} \mid F D, F D^{2}, G D P\right)$. Whenever the calculated $F$-statistic exceeded the upper critical bound, we concluded there is a long-run co-integration between the variables. To make sure the estimated models were in stable condition, we conducted diagnostic tests along with the CUSUM and CUSUMQ tests stability.

Once the F-statistic confirmed the existence of a long-run co-integration between the variables, the long-run and the short-run models were then estimated following the selected lag order through the ARDL models. Following Pesaran et al. (2001), we obtained the error correction coefficient by replacing the lag of the level variables in Eq. (6) with an error term $\left(E C T_{t-1}\right)$. This can be written as follows: 


$$
\begin{gathered}
\Delta \operatorname{Tax}_{t}=\beta_{0}+\beta_{T} T+\sum_{i=1}^{p} \alpha_{1} \Delta \operatorname{Tax}_{t-i}+\sum_{j=0}^{q} \alpha_{2} \Delta F D_{t-j}+\sum_{k=0}^{r} \alpha_{3} \Delta G D P_{t-k}+\sum_{l=0}^{s} \alpha_{4} \Delta G D P_{t-l}^{2}+ \\
\varphi E C T_{t-1}+\varepsilon_{1 t} ; \\
\Delta \operatorname{Tax}_{t}=\beta_{0}+\beta_{T} T+\sum_{i=1}^{p} \alpha_{1} \Delta \operatorname{Tax}_{t-i}+\sum_{j=0}^{q} \alpha_{2} \Delta F D_{t-j}+\sum_{k=0}^{r} \alpha_{3} \Delta F D_{t-l}^{2}+\sum_{l=0}^{s} \alpha_{4} \Delta G D P_{t-j}+ \\
\varphi E C T_{t-1}+\varepsilon_{1 t},
\end{gathered}
$$

where, $T$ and $\varphi$ coefficients represent the break date, and the error term of the TY model. To make sure the estimated models were in stable condition, we conducted diagnostic tests along with the CUSUM and CUSUMQ tests stability.

After confirming that long-run co-integration exists between tax revenues, financial development and economic growth, the next stage of estimation was the causal effects analysis. In this study, we emphasized linear and nonlinear approaches using Toda and Yamamoto (TY) (1995), and Diks and Panchenko (2006), respectively. Eq. (7) shows the TY causality estimates between taxation, financial development and economic growth.

$$
\begin{gathered}
\operatorname{Tax}_{t}=\alpha_{0}+\sum_{i=1}^{k} \alpha_{1} \operatorname{Tax}_{t-i}+\sum_{j=k+1}^{d_{\max }} \alpha_{2 j} \operatorname{Tax}_{t-j}+\sum_{i=1}^{k} \delta_{1} F D_{t-i}+\sum_{j=k+1}^{d_{\max }} \delta_{2 j} F D_{t-j}+\sum_{i=1}^{k} \varphi_{1} G D P_{t-i}+ \\
\sum_{j=k+1}^{d_{\max }} \varphi_{2 j} G D P_{t-j}+\sum_{i=1}^{k} \theta_{1} G D P_{t-i}^{2}+\sum_{j=k+1}^{d_{\max }} \theta_{2 j} G D P_{t-j}^{2}+\epsilon_{t} .
\end{gathered}
$$

The maximum integrated level based on the ZA unit root test was $d_{\text {max }}=1$; and the lag length $(k)$ was based on VAR estimates. In particular, the TY model emphasized $\operatorname{VAR}\left(d_{\text {max }}+k\right)=2$ and we examined the causal relationship based on the modified WALD estimates. When the Granger causality ran from FD, GDP and GDP ${ }^{2}$, this was stated as $\delta_{1,2} \neq 0 \forall_{i}, \quad \varphi_{1,2} \neq 0 \forall_{i}$ and $\theta_{1,2} \neq 0 \forall_{i}$. respectively. The recent nonparametric Granger causality test proposed by Diks and Panchenko (2006) is able to reduce the biases and weaken the risk of over-rejection of the null hypothesis. At the first stage, Granger (1969) proposed a causality test to describe the relations between $X_{t}$ and $Y_{t}$ variables; where we considered both series mean is equal to $E\left(Y_{t+1} \mid\left(F_{X_{t}}, F_{Y_{t}}\right)\right)$. In the nonlinear causality, we took into consideration past observation of $X_{t}^{\ell_{x}}$ which contained more information about the future observation of $Y_{t}^{\ell_{x}}$, where $\ell_{x}, \ell_{y} \geq 1$. If the null hypothesis was rejected, we assumed that there is causality running between 2 variables. However, before testing the nonlinear causality test, it was thought better if we confirmed the presence of the nonlinearity of each series using the BDS test based on the independently and identically distributes (IID) assumption (Brock, Sheinkman, Dechert, \& LeBaron, 1996; Dergiades, Martinopoulos, \& Tsoulfidis, 2013). The null hypothesis of nonlinear Diks and Panchenko (2006) is as follows:

$$
H_{0}=Y_{t+1}\left|\left(X_{t}^{\ell_{x}}, Y_{t}^{\ell_{y}}\right) \sim Y_{t+1}\right| Y_{t}^{\ell_{y}} .
$$

At the end of the empirical strategies, we employed the Sasabuchi-Lind-Mehlum (SLM) U-test proposed by Lind and Mehlum (2010) to capture the U-shaped or inverted U-shape 
relationships. We used this test to fulfil the ARDL models which consider the quadratic form of GDP and FD conditions. The following models were used to estimate the task:

$$
\begin{gathered}
\operatorname{Tax}_{t}=\alpha G D P_{t}+\beta G D P_{t}^{2}+Z_{t} C+\varepsilon_{t} ; \\
\operatorname{Tax}_{t}=\alpha F D_{t}+\beta F D_{t}^{2}+Z_{t} C+\varepsilon_{t},
\end{gathered}
$$

where, the null and alternative hypothesis for SLM test can be illustrated as:

$$
\begin{gathered}
H_{0}=\left(\alpha+\beta 2 G D P_{\min } \leq 0\right) \cup\left(\alpha+\beta 2 G D P_{\max } \geq 0\right) \text { vs. } \\
H_{1}=\left(\alpha+\beta 2 G D P_{\min }>0\right) \cup\left(\alpha+\beta 2 G D P_{\max }<0\right) ; \\
H_{0}=\left(\alpha+\beta 2 F D_{\min } \leq 0\right) \cup\left(\alpha+\beta 2 F D_{\max } \geq 0\right) \text { vs. } \\
H_{1}=\left(\alpha+\beta 2 F D_{\text {min }}>0\right) \cup\left(\alpha+\beta 2 F D_{\max }<0\right),
\end{gathered}
$$

where, once the null hypothesis is rejected, this confirms the U-shape condition of the estimation.

\section{Empirical results}

Table 2 explains the establishment of a financial development index, where in order to select the principal component, we used three indicators to include the banking sector (percentage of GDP) for PC1, domestic credit to the private sector (percentage of GDP) for PC2, and money and quasi money (percentage of GDP) for PC3. All of the three PC's turned out with the standardized variance of $97.1 \%, 2 \%$ and $0.5 \%$, respectively. After investigating the variations, we decide to choose PC1 to calculate the financial development index for Malaysia. The second section of Table 2 indicates the eigenvectors that represent the weighted value of the measured financial development index. The full-length of the financial development series took place in Figure 1, where we can see the volatile conditions, especially during the Asian financial and oil price crises. This finding confirms that, there was an unstable condition over the period of the data series used in this study.

Table 2. Financial development index analysis

\begin{tabular}{|l|c|c|c|c|}
\hline & Eigenvalues & Difference & Variation (\%) & Cumulative (\%) \\
\hline PC1 & 2.915 & 2.848 & 0.971 & 97.1 \\
\hline PC2 & 0.066 & 0.049 & 0.022 & 99.4 \\
\hline PC3 & 0.017 & & 0.005 & 100.0 \\
\cline { 2 - 4 } & \multicolumn{3}{|c|}{ Eigenvectors } \\
\cline { 2 - 4 } & PC1 & PC2 & PC3 & \\
\cline { 2 - 4 } $\ln$ lnPank & 0.582 & -0.079 & -0.809 & \\
\cline { 1 - 4 } $\ln$ In2 & 0.574 & 0.744 & 0.340 & \\
\hline
\end{tabular}




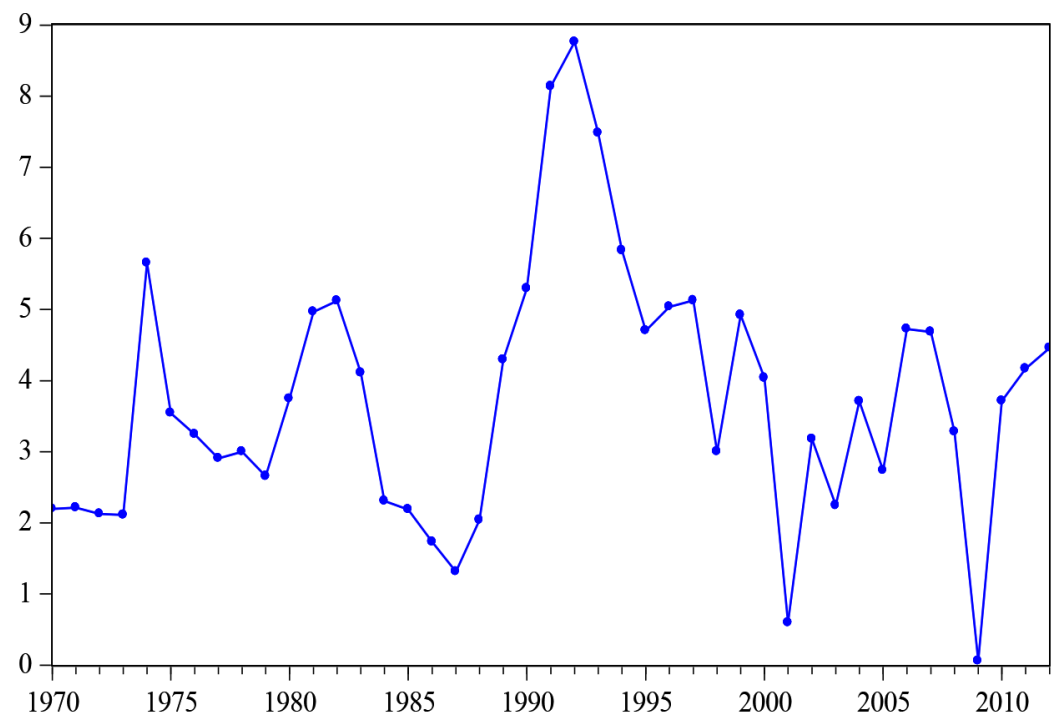

Figure 1. Financial development index

The existing empirical literature using the ARDL bound testing co-integration mostly depends on the variables at $I(0)$ or $I(1)$ being stationary, or the variables being in mixed stationary order of integration. The ARDL estimates will not be valid, in the case where there are $I(2)$ variables. Most traditional unit root tests do not provide information about structural breaks and to solve this problem, we used ZA with a single break occurring in the data series. As a result, we noted that the null hypothesis of a unit root cannot be rejected at level stage for all variables and the null hypothesis of non-stationary is rejected when all variables are in first difference as presented in Table 3. Therefore, we concluded that all variables are integrated at $I(1)$. At this point, our empirical exercise illustrated that taxation and GDP break dates detected from the ZA unit root test correspond with the Asian financial crisis between the periods of 1996 until 1998. The break in the financial development variable is related to the global oil price crisis in the mid-1980s, where the Malaysian government faced inflation, unemployment and financial activities were in sustain mode. Although the country faced financial instability, Malaysia reformed the foreign direct investment and trade policies which impacted on trade liberalization and improved overall government revenue and GDP in the 1980's.

After confirming the evidence of all variables integrated at $I(1)$, the next step was to examine the long-run co-integration using the ARDL bounds test. Lag length selection was one of the sensitive aspects arising when we used the ARDL co-integration testing. In this context, we used the Akaike Information Criterion (AIC) to choose the optimal lag order. The specification of 5 types of lag length criteria is reported in Table 4. We followed AIC to choose the lag length and from the results, the lag length was $k=2$ and $k=3$, respectively, for Eq. (2) and (3) which illustrate the VAR estimates. 
Table 3. Results of unit root test

\begin{tabular}{|l|c|c|c|c|}
\hline \multirow{2}{*}{ Variables } & \multicolumn{2}{c|}{ At level } & \multicolumn{2}{c|}{ At first difference } \\
\cline { 2 - 5 } & ZA-stat & Break date & ZA-stat & Break date \\
\hline Tax & -3.723 & 1998 & $-6.278^{\star}$ & 1988 \\
\hline FD & -4.665 & 1985 & $-5.958^{\star}$ & 1985 \\
\hline FD & -4.592 & 1985 & $-6.878^{\star}$ & 1985 \\
\hline GDP & -2.724 & 1996 & $-6.479^{\star}$ & 1988 \\
\hline GDP $^{2}$ & -2.629 & 1997 & $-6.442^{\star}$ & 1988 \\
\hline
\end{tabular}

Note: ${ }^{\star},{ }^{*}$ and ${ }^{* *}$ indicates the significance level at $1 \%, 5 \%$ and $10 \%$ respectively.

Table 4. Lag length selection criteria

\begin{tabular}{|c|c|c|c|c|c|}
\hline \multirow{2}{*}{ Lag length } & \multicolumn{5}{|c|}{$\operatorname{Tax}_{t}=\beta_{1}+\beta_{2} F D_{t}+\beta_{3} G D P_{t}+\beta_{4} G D P_{t}^{2}+\mu_{t}$} \\
\hline & $\log L$ & FPE & AIC & SC & HQ \\
\hline 0 & 55.103 & $9.05 e-08$ & -4.866 & -4.668 & -4.823 \\
\hline 1 & 152.580 & $4.00 \mathrm{e}-11^{\star}$ & -12.626 & $-11.631^{\star}$ & $-12.410^{\star}$ \\
\hline 2 & 169.163 & $4.62 \mathrm{e}-11$ & $-12.682^{*}$ & -10.891 & -12.293 \\
\hline 3 & 179.529 & $1.44 \mathrm{e}-10$ & -12.145 & -9.559 & -11.584 \\
\hline \multirow{2}{*}{ Lag length } & \multicolumn{5}{|c|}{$\operatorname{Tax}_{t}=\alpha_{1}+\alpha_{2} G D P_{t}+\alpha_{3} F D_{t}+\alpha_{4} F D_{t}^{2}+v_{t}$} \\
\hline & $\log L$ & FPE & $\mathrm{AIC}$ & SC & HQ \\
\hline 0 & 54.366 & $9.70 \mathrm{e}-08$ & -4.796 & -4.597 & -4.753 \\
\hline 1 & 117.723 & $1.11 \mathrm{e}-09^{*}$ & -9.307 & $-8.312^{\star}$ & $-9.091^{\star}$ \\
\hline 2 & 129.324 & $2.06 \mathrm{e}-09$ & -8.888 & -7.097 & -8.4994 \\
\hline 3 & 151.180 & $2.14 \mathrm{e}-09$ & $-9.445^{\star}$ & -6.859 & -8.884 \\
\hline
\end{tabular}

Note: ${ }^{*}$ indicates optimal lag order selected by the criterion.

Table 5 provides the results of the ARDL bounds testing approach to the long-run cointegration. The computed F-bounds were compared with the upper (UB) and lower bound (LB) using Pesaran et al. (2001)'s critical bounds. Our empirical findings indicate only three co-integrating vectors validated the existence of long-run co-integration between tax revenues, financial development and economic growth in Malaysia. Furthermore, we have included the interaction between the squared terms of FD on tax revenue function as shown in Table 6. We found that the computed F-statistics were at 6.743, 1.499, 2.117 and 2.336, respectively. Interestingly, we found only one co-integrating vector validated the existence of long-run co-integration between tax revenue, financial development and GDP growth in Malaysia. After investigating the robustness of the long-run relationship, the next stage was to estimate the ARDL-ECM model. Table 7 presents the results of the ARDL-ECM shortand long-run relationship between the variables. A $1 \%$ rise in economic growth is associated with $0.652 \%$ of tax revenues and this finding could not indicate any quadratic relation for the long-run because the squared GDP is not able to reject the null hypothesis. Bujang, Abu 
Hakim, and Ahmad (2013) and Abdullah and Morley (2014) also drew the same inference with growth-led-taxation in the long-run. In addition, in the short-run, the linear term coefficient of GDP was also positive at $1 \%$ significance level. It shows that an increase in GDP results in an increase in tax revenues. It seems that the positive contribution to GDP in the long-run was much higher from the short-run effect because the economic condition was more stable after facing the Asian financial crises in the late 1990's.

Meanwhile, the squared GDP series which represents the quadratic effect was found to be positively sloped and significant at -0.337 and -0.081 in the long and short-run period, respectively. This indicates there is a $\mathrm{U}$-shape effect of economic growth on taxation. This positive and significant sign seems to affect the increasing of taxation and GDP at the higher levels of income.

Table 5. The results for ARDL cointegration test

\begin{tabular}{|l|c|c|c|c|c|c|}
\hline \multicolumn{1}{|c|}{ Estimated models } & $\begin{array}{c}\text { Optimal } \\
\text { lag }\end{array}$ & $T_{B}$ & F-stat & $\chi_{\text {Serial }}^{2}$ & $\chi_{\text {ARCH }}^{2}$ & $\chi_{\text {Normal }}^{2}$ \\
\hline Tax $=f\left(F D, G D P, G D P^{2}\right)$ & $(1,0,2,0,1)$ & 1998 & $3.894^{* *}$ & $\begin{array}{c}1.340 \\
(0.247)\end{array}$ & $\begin{array}{c}0.571 \\
(0.450)\end{array}$ & $\begin{array}{c}4.867^{* * *} \\
(0.088)\end{array}$ \\
\hline$F D=f\left(\operatorname{Tax}, G D P, G D P^{2}\right)$ & $(1,0,0,0,0)$ & 1985 & 1.876 & $\begin{array}{c}0.580 \\
(0.446)\end{array}$ & $\begin{array}{c}0.994 \\
(0.319)\end{array}$ & $\begin{array}{c}73.163^{*} \\
(0.000)\end{array}$ \\
\hline$G D P=f\left(F D, T a x, G D P^{2}\right)$ & $(1,0,0,1,0)$ & 1996 & $3.464^{* * *}$ & $\begin{array}{c}1.228 \\
(0.268)\end{array}$ & $\begin{array}{c}1.739 \\
(0.187)\end{array}$ & $\begin{array}{c}39.438^{*} \\
(0.000)\end{array}$ \\
\hline$G D P^{2}=f(F D, T a x, G D P)$ & $(1,0,0,1,2)$ & 1997 & $3.387^{* * *}$ & $\begin{array}{c}0.554 \\
(0.456)\end{array}$ & $\begin{array}{c}1.067 \\
(0.302)\end{array}$ & $\begin{array}{c}43.317^{*} \\
(0.000)\end{array}$ \\
\hline Significant level & Critical bounds & & & & \\
\cline { 1 - 4 } 1 percent & $\mathrm{I}(0)$ & $\mathrm{I}(1)$ & & & & \\
\hline 5 percent & 3.516 & 4.781 & & & & \\
\hline 10 percent & 2.649 & 3.805 & & & & \\
\hline
\end{tabular}

Note: ${ }^{*},{ }^{* *}$ and ${ }^{* * *}$ indicates $1 \%, 5 \%$, and $10 \%$ level of statistical significance.

Table 6. The results for ARDL cointegration test

\begin{tabular}{|l|c|c|c|c|c|c|}
\hline \multicolumn{1}{|c|}{ Estimated models } & Optimal lag & $T_{B}$ & $F$-stat & $\chi_{\text {Serial }}^{2}$ & $\chi_{\text {ARCH }}^{2}$ & $\chi_{\text {Normal }}^{2}$ \\
\hline Tax $=f\left(F D, F D^{2}, G D P\right)$ & $(3,3,0,0,1)$ & 1998 & $6.743^{*}$ & $\begin{array}{c}0.517 \\
(0.472)\end{array}$ & $\begin{array}{c}0.012 \\
(0.910)\end{array}$ & $\begin{array}{c}0.258 \\
(0.879)\end{array}$ \\
\hline$G D P=f\left(\operatorname{Tax}, F D, F D^{2}\right)$ & $(3,1,3,2,3)$ & 1996 & 1.499 & $\begin{array}{c}4.296^{* *} \\
(0.038)\end{array}$ & $\begin{array}{c}1.535 \\
(0.215)\end{array}$ & $\begin{array}{c}32.931^{*} \\
(0.000)\end{array}$ \\
\hline$F D=f\left(\operatorname{Tax}, G D P, F D^{2}\right)$ & $(2,1,1,1,1)$ & 1985 & 2.117 & $\begin{array}{c}0.042 \\
(0.836)\end{array}$ & $\begin{array}{c}0.428 \\
(0.513)\end{array}$ & $\begin{array}{c}56.251^{*} \\
(0.000)\end{array}$ \\
\hline$F D^{2}=f(\operatorname{Tax}, F D, G D P)$ & $(1,0,0,1,2)$ & 1985 & 2.336 & $\begin{array}{c}0.164 \\
(0.685)\end{array}$ & $\begin{array}{c}0.280 \\
(0.596)\end{array}$ & $\begin{array}{c}36.327^{*} \\
(0.000)\end{array}$ \\
\hline Significant level & \multicolumn{2}{|c|}{ Critical bounds } & & & & \\
\cline { 2 - 8 } & \multicolumn{2}{|c|}{$\mathrm{I}(0)$} & $\mathrm{I}(1)$ & & & \\
\hline
\end{tabular}


End of Table 6

\begin{tabular}{|c|c|c|c|c|c|c|}
\hline Estimated models & Optimal lag & $T_{B}$ & F-stat & $\chi_{\text {Serial }}^{2}$ & $\chi_{A R C H}^{2}$ & $\chi_{\text {Normal }}^{2}$ \\
\hline 1 percent & 3.516 & 4.781 & & & & \\
\hline 5 percent & 2.649 & 3.805 & & & & \\
\hline 10 percent & 2.262 & 3.367 & & & & \\
\hline
\end{tabular}

Note: ${ }^{*}{ }^{* *}$ and ${ }^{* *}$ indicates $1 \%, 5 \%$, and $10 \%$ level of statistical significance.

Table 7. The results for ARDL-ECM $(1,0,2,0,1)$ results

\begin{tabular}{|c|c|c|c|c|c|}
\hline \multicolumn{3}{|c|}{ Long-run estimates } & \multicolumn{3}{|c|}{ Short-run estimates } \\
\hline Regressor & Coefficient & Std. error & Regressor & Coefficient & Std. error \\
\hline$F D$ & -0.020 & 0.141 & $\triangle F D$ & -0.004 & 0.035 \\
\hline$G D P$ & $0.652^{*}$ & 0.211 & $\triangle G D P$ & $0.402^{*}$ & 0.120 \\
\hline$G D P^{2}$ & $0.337^{\star}$ & 0.102 & $\Delta G D P^{2}$ & $0.081^{\star *}$ & 0.031 \\
\hline \multirow[t]{4}{*}{$T_{B}$} & 0.314 & 0.337 & $T_{B}$ & -0.115 & 0.117 \\
\hline & & & $E C T_{t-1}$ & $-0.241^{\star * *}$ & 0.120 \\
\hline & \multicolumn{5}{|c|}{ Diagnostic tests } \\
\hline & $\chi^{2}$-statistic & $\mathrm{p}$-value & & $\chi^{2}$-statistic & p-value \\
\hline$\chi_{\text {Serial }}^{2}$ & 1.731 & 0.188 & $\chi_{A R C H}^{2}$ & 2.276 & 0.131 \\
\hline$\chi_{R E S E T}^{2}$ & 0.172 & 0.677 & $\chi_{\text {Normal }}^{2}$ & 0.287 & 0.866 \\
\hline
\end{tabular}

Note: ${ }^{*}{ }^{* *}$ and ${ }^{* * *}$ indicates $1 \%, 5 \%$, and $10 \%$ level of statistical significance, respectively. The $T_{B}=1998$, which refers to the break date.

Table 8. The results for ARDL-ECM $(3,3,0,0,1)$ results

\begin{tabular}{|c|c|c|c|c|c|}
\hline \multicolumn{3}{|c|}{ Long-run estimates } & \multicolumn{3}{c|}{ Short-run estimates } \\
\hline Regressor & Coefficient & Std. error & Regressor & Coefficient & Std. error \\
\hline$G D P$ & $0.995^{*}$ & 0.268 & $\Delta F D$ & $0.337^{\star}$ & 0.069 \\
\hline$F D$ & $0.151^{*}$ & 0.036 & $\Delta F D$ & 0.017 & 0.056 \\
\hline$F D^{2}$ & $-0.113^{\star *}$ & 0.043 & $\Delta F D^{2}$ & -0.012 & 0.033 \\
\hline$T_{B}$ & 1.374 & 1.945 & $T_{B}$ & -0.0500 & 0.111 \\
\hline & & & $E C T_{t-1}$ & $-0.112^{*}$ & 0.026 \\
\hline & $\chi^{2}$-statistic & p-value & & & Diagnostic tests \\
\hline$\chi_{\text {Serial }}^{2}$ & 0.478 & 0.827 & $\chi_{\text {ARCH }}^{2}$ & 1.271 & 0.260 \\
\hline$\chi_{F F}^{2}$ & 0.089 & 0.765 & $\chi_{\text {Normal }}^{2}$ & 1.651 & 0.438 \\
\hline
\end{tabular}

Note: ${ }^{*}{ }^{* *}$ and ${ }^{* *}$ indicates $1 \%, 5 \%$, and $10 \%$ level of statistical significance, respectively. The $T_{B}=1998$, which refers to the break date. 
The FD negatively impacted GDP sustainability as shown in Table 8. We also found that the squared FD series is negatively significant with GDP and this confirms an inverted- $U$ shape condition, where $1 \%$ increase in FD increases tax collection by $0.151 \%$, while the squared term seems to corroborate with a decreasing $(-0.113 \%)$ condition tax collection. This reveals that tax collection increases with financial development and starts to decrease after a threshold level of financial development. This may happen due to the depreciation of the Malaysian Ringgit when people tend to invest in the stock market, which in turn will reduce the money demand in the open market. Furthermore, when the financial development reaches threshold level with the uncertainty of the global economy, the government diverts the focus to the development of other sectors which are more secure and can survive from external factors. Therefore, as financial development increased, the tax revenues have also increased consistently. Indeed, in Malaysia, over $44 \%$ of tax revenues are related to petroleum resources, and the recent adoption of the well-planned collection of Good and Services Tax (GST) has contributed to diversify the overall tax revenue in Malaysia.

When discussing the $E C T_{t-1}$, this study has captured the correct negative sign and significance at $10 \%$ and $1 \%$ confidence levels, respectively. Therefore, any changes of deviation from the short-run equilibrium between the variables will be corrected for each period to sustain in the long-run equilibrium stage as fast as $24.1 \%$ and $11.2 \%$ levels (see Table 7 and 8). The diagnostic test results also confirm the estimated long- and short-run ARDL-ECM models are totally free from serial correlation, heteroscedasticity, normality and functional form misspecification problems. The CUSUM and CUSUMQ plots are well-located within the $5 \%$ critical bounds and confirm to us the estimated mode is defiantly in a stable mode as shown in Figures 2 and 3.

This study also explores the causal relationship using linear and nonlinear approaches. Table 9 presents the results of the TY Granger causality between tax revenue, financial development and economic growth, which represent the linear causal condition. In the previous section, we found the long-run relationship between the variables, and therefore we decided to capture the short-run causalities. The results illustrated in Table 9 indicate that a bi-directional causality exists between taxation and economic growth. Furthermore, we also explore
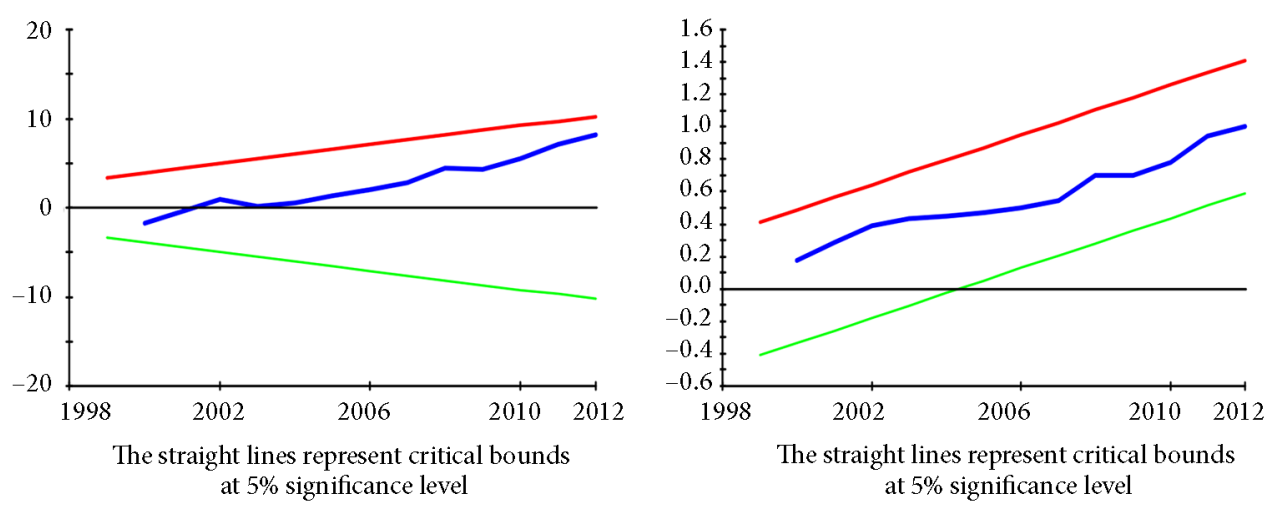

Figure 2. CUSUM and CUSUMQ 

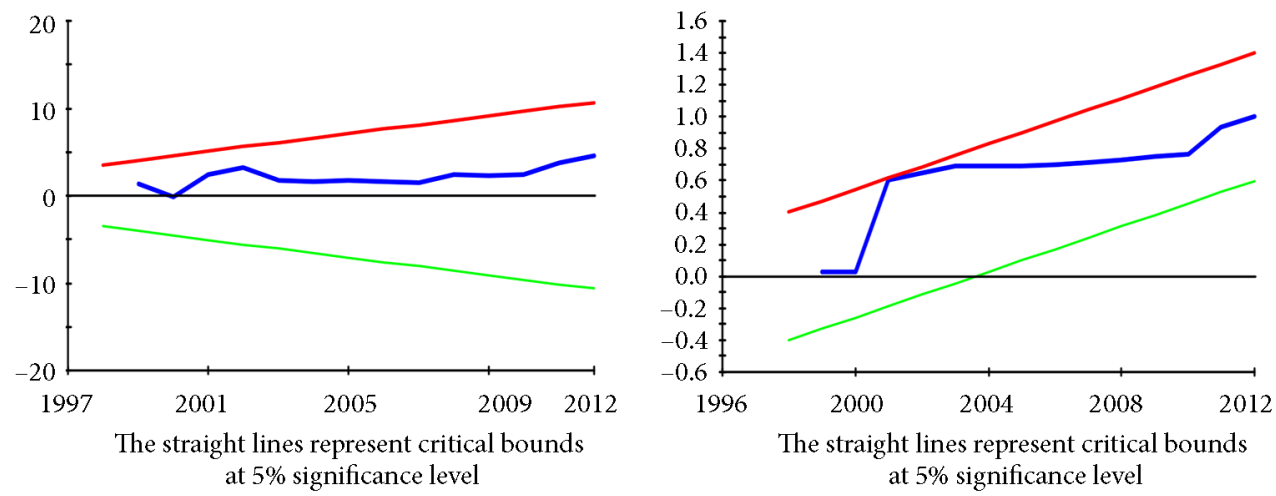

Figure 3. CUSUM and CUSUMQ diagrams

the causal relationship between the tax revenue, economic growth and financial development squared series. In the previous section, we found the long-run relationship between these variables, and therefore we decided to capture the short-run causality between the variables. The results illustrated in Table 10 are once again similar to the results in Table 9, where we found a uni-directional causality exists between GDP and FD on taxation. Our results are consistent with the earlier findings of Romero-Ávila and Strauch (2008), and Abdullah and Morley (2014).

Table 9. Toda-Yamamoto Granger causality results with GDP squared

\begin{tabular}{|c|c|c|c|c|}
\hline \multirow{2}{*}{} & \multicolumn{4}{|c|}{$M W A L D\left(\chi^{2}\right)=d_{\text {max }}+k$} \\
\cline { 2 - 5 } & Tax & $F D$ & $G D P$ & $G D P^{2}$ \\
\hline \multirow{2}{*}{ Tax } & - & 0.902 & $29.586^{*}$ & $27.911^{\star}$ \\
& 0.009 & $(0.342)$ & $(0.000)$ & $(0.000)$ \\
\hline \multirow{2}{*}{$F D$} & $(0.922)$ & - & 0.025 & 0.034 \\
& $4.738^{* *}$ & 0.823 & $(0.873)$ & $(0.852)$ \\
\hline \multirow{2}{*}{$G D P$} & $(0.029)$ & $(0.364)$ & - & $513.47^{*}$ \\
& $4.390^{* *}$ & 0.808 & $510.68^{*}$ & $(0.000)$ \\
\hline \multirow{2}{*}{$G D P^{2}$} & $(0.036)$ & $(0.368)$ & $(0.000)$ & - \\
& & &
\end{tabular}

Note: ${ }^{*}{ }^{* *}$ and ${ }^{* * *}$ indicates $1 \%, 5 \%$, and $10 \%$ level of statistical significance and $p$-values.

Generally, the BDS test is able to identify the linearization of a series within a standard bivariate VAR framework (Dergiades et al., 2013). Table 11 and Table 12 present the BDS test results proposed by Brock et al. (1996). We estimated the BDS statistics based on the residual unrestricted VAR specification. The estimated results indicate significance level BDS statistics at $1 \%$ and this result gives a positive indication for us to use the nonlinear causality test in this study. 
Table 10. Toda-Yamamoto Granger causality results with FD squared

\begin{tabular}{|c|c|c|c|c|}
\hline \multirow{2}{*}{} & \multicolumn{4}{|c|}{$M W A L D\left(\chi^{2}\right)=d_{\text {max }}+k$} \\
\cline { 2 - 5 } & Tax & $G D P$ & $F D$ & $F D^{2}$ \\
\hline \multirow{2}{*}{ Tax } & - & $9.961^{\star *}$ & $13.591^{\star}$ & $23.144^{\star}$ \\
& 0.551 & $(0.018)$ & $(0.003)$ & $(0.000)$ \\
\hline \multirow{2}{*}{$G D P$} & $(0.907)$ & - & 1.935 & $9.910^{* *}$ \\
& 4.132 & 0.94 & $(0.586)$ & $(0.019)$ \\
\hline \multirow{2}{*}{$F D$} & $(0.247)$ & $(0.815)$ & - & 3.739 \\
& 3.854 & 5.798 & 3.408 & $(0.290)$ \\
\hline \multirow{2}{*}{$F D^{2}$} & $(0.277)$ & $(0.121)$ & $(0.332)$ & - \\
& & & & \\
\hline
\end{tabular}

Note: ${ }^{*}{ }^{* *}$ and ${ }^{* * *}$ indicates $1 \%, 5 \%$, and $10 \%$ level of statistical significance and p-values.

Table 11. BDS test results for $\operatorname{Tax}=f\left(G D P, G D P^{2}, F D\right)$

\begin{tabular}{|c|c|c|c|c|}
\hline Dimension & BDS statistic & Std. error & $z$-statistic & $p$-value \\
\hline 2 & 0.002 & 0.000 & $2.953^{\star}$ & 0.003 \\
\hline 3 & 0.001 & 0.000 & $5.944^{*}$ & 0.000 \\
\hline
\end{tabular}

Note: ${ }^{*},{ }^{* *}$ and ${ }^{* * *}$ indicates $1 \%, 5 \%$, and $10 \%$ level of statistical significance, respectively. The VAR lag order was selected based on the AIC.

Table 12. BDS test results for Tax $=f\left(G D P, F D, F D^{2}\right)$

\begin{tabular}{|c|c|c|c|c|}
\hline Dimension & BDS statistic & Std. error & $z$-statistic & $p$-value \\
\hline 2 & 0.042 & 0.021 & $1.964^{* *}$ & 0.049 \\
\hline 3 & 0.079 & 0.034 & $2.300^{* *}$ & 0.021 \\
\hline
\end{tabular}

Note: ${ }^{*},{ }^{* *}$ and ${ }^{* * *}$ indicates $1 \%, 5 \%$, and $10 \%$ level of statistical significance, respectively. The VAR lag order was selected based on the AIC.

Table 13. Nonlinear causality results

\begin{tabular}{|c|c|c|c|c|c|}
\hline \multirow{2}{*}{$\ell_{x}=\ell_{y}$} & \multirow{2}{*}{ Bandwith $(\varepsilon)$} & $t$-statistic & $p$-value & $t$-statistic & $p$-value \\
\hline & & \multicolumn{2}{|c|}{$H_{0}:$ Tax $-/ \rightarrow F D$} & \multicolumn{2}{|c|}{$H_{0}: F D-/ \rightarrow \operatorname{Tax}$} \\
\hline \multirow[t]{2}{*}{1} & 0.5 & 0.929 & 0.176 & 0.494 & 0.310 \\
\hline & 1.0 & 0.412 & 0.340 & 0.459 & 0.677 \\
\hline \multirow[t]{2}{*}{2} & 0.5 & 0.754 & 0.225 & 0.212 & 0.583 \\
\hline & 1.0 & 0.290 & 0.613 & 0.161 & 0.564 \\
\hline & & \multicolumn{2}{|c|}{$H_{0}:$ Tax $-/ \rightarrow G D P$} & \multicolumn{2}{|c|}{$H_{0}: G D P-/ \rightarrow \operatorname{Tax}$} \\
\hline \multirow[t]{2}{*}{1} & 0.5 & $1.362^{\star \star \star}$ & 0.086 & $1.432^{\star \star \star *}$ & 0.076 \\
\hline & 1.0 & 0.688 & 0.245 & $1.470^{\star * \star}$ & 0.070 \\
\hline \multirow[t]{2}{*}{2} & 0.5 & 0.962 & 0.167 & 1.235 & 0.108 \\
\hline & 1.0 & 0.625 & 0.265 & $1.373^{\star * *}$ & 0.084 \\
\hline
\end{tabular}


End of Table 13

\begin{tabular}{|c|c|c|c|c|c|}
\hline \multirow{2}{*}{$\ell_{x}=\ell_{y}$} & \multirow{2}{*}{ Bandwith $(\varepsilon)$} & $t$-statistic & $p$-value & $t$-statistic & $p$-value \\
\cline { 3 - 6 } & & \multicolumn{2}{|c|}{$H_{0}:$ Tax $-/ \rightarrow F D$} & \multicolumn{2}{|c|}{$H_{0}: F D-/ \rightarrow$ Tax } \\
\hline \multicolumn{2}{|c|}{} & \multicolumn{2}{|c|}{$\boldsymbol{H}_{0}:$ Tax $-/ \rightarrow G D P^{2}$} & \multicolumn{2}{|c|}{$H_{0^{*}}: G D P^{2}-/ \rightarrow$ Tax } \\
\hline 1 & 0.5 & $1.216^{* * *}$ & 0.092 & $1.592^{* * *}$ & 0.055 \\
\hline & 1.0 & 0.319 & 0.375 & $1.471^{* * *}$ & 0.070 \\
\hline 2 & 0.5 & 0.067 & 0.473 & $1.486^{* * *}$ & 0.068 \\
\hline & 1.0 & 0.319 & 0.374 & $1.373^{* * *}$ & 0.084 \\
\hline
\end{tabular}

Note: ${ }^{\star},{ }^{\star \star}$ and ${ }^{\star * \star}$ indicates $1 \%, 5 \%$, and $10 \%$ level of statistical significance, respectively.

In Table 13, we reported the Diks and Panchenko (2006) nonlinear causality results. We used bi-directional direction for $\ell_{x}=\ell_{y}=1, \ldots 2$ with the Bandwidth $\varepsilon=0.5,1.0$ and 1.5 set according to the time series length $T=43$. In fact, the nonlinear results obtained from the Diks and Panchenko (2006) causality analysis indicate that the bi-directional causality exits run between taxation and GDP growth, and once again there is a neutral hypothesis between taxation and financial development. There is strong evidence for the existence of nonlinear causality from taxation to economic growth. The results of nonlinear causality reported in Table 14 reveal that the bi-directional causality runs between GDP and FD on taxation. This result is against the linear causality test, which indicates the unidirectional causality running between taxation and GDP. Surprisingly, both linear and nonlinear estimates indicate the unidirectional causal relationship running from taxation on FD. According to Bodman et al. (2012) and Ho and Yang (2013), taxation may affect economic growth and later influence financial development. This indication might be a useful hint for us where a strong causal relationship between GDP and taxation is able to increase financial activity and further reflect the collection of taxation revenue in Malaysia.

Table 14. Nonlinear causality results

\begin{tabular}{|c|c|c|c|c|c|}
\hline \multirow{2}{*}{$\ell_{x}=\ell_{y}$} & \multirow{2}{*}{ Bandwith $(\varepsilon)$} & $t$-statistic & $p$-value & $t$-statistic & $p$-value \\
\hline & & \multicolumn{2}{|c|}{$H_{0}:$ Tax $-/ \rightarrow G D P$} & \multicolumn{2}{|c|}{$H_{0}: G D P-/ \rightarrow \operatorname{Tax}$} \\
\hline \multirow[t]{2}{*}{1} & 0.5 & $1.362^{\star * *}$ & 0.086 & $1.432^{\star * *}$ & 0.076 \\
\hline & 1.0 & 0.688 & 0.245 & $1.470^{\star * *}$ & 0.070 \\
\hline \multirow[t]{3}{*}{2} & 0.5 & 0.962 & 0.167 & 1.235 & 0.108 \\
\hline & 1.0 & 0.625 & 0.265 & 1.373 & 0.184 \\
\hline & & \multicolumn{2}{|c|}{$H_{0}:$ Tax $-/ \rightarrow F D$} & \multicolumn{2}{|c|}{$H_{0}: F D-/ \rightarrow \operatorname{Tax}$} \\
\hline \multirow[t]{2}{*}{1} & 0.5 & $1.929^{* * *}$ & 0.076 & 0.499 & 0.970 \\
\hline & 1.0 & 0.412 & 0.340 & 0.459 & 0.677 \\
\hline \multirow[t]{3}{*}{2} & 0.5 & 0.754 & 0.225 & 0.212 & 0.583 \\
\hline & 1.0 & 0.290 & 0.613 & 0.161 & 0.564 \\
\hline & & \multicolumn{2}{|c|}{$H_{0}: T a x-/ \rightarrow F D^{2}$} & \multicolumn{2}{|c|}{$H_{0}: F D^{2}-I \rightarrow \operatorname{Tax}$} \\
\hline
\end{tabular}


End of Table 14

\begin{tabular}{|c|c|c|c|c|c|}
\hline \multirow{2}{*}{$\ell_{x}=\ell_{y}$} & \multirow{2}{*}{ Bandwith $(\varepsilon)$} & $t$-statistic & $p$-value & $t$-statistic & $p$-value \\
\hline & & \multicolumn{2}{|c|}{$H_{0}:$ Tax $-/ \rightarrow G D P$} & \multicolumn{2}{|c|}{$H_{0}: G D P-/ \rightarrow \operatorname{Tax}$} \\
\hline \multirow[t]{2}{*}{1} & 0.5 & $1.874^{\star * *}$ & 0.070 & 0.691 & 0.974 \\
\hline & 1.0 & 0.549 & 0.708 & 0.001 & 0.500 \\
\hline \multirow[t]{2}{*}{2} & 0.5 & 0.436 & 0.331 & 0.922 & 0.178 \\
\hline & 1.0 & 0.051 & 0.479 & 0.753 & 0.225 \\
\hline
\end{tabular}

Note: ${ }^{*}{ }^{* *}$ and ${ }^{* *}$ indicates $1 \%, 5 \%$, and $10 \%$ level of statistical significance, respectively.

As we have discussed earlier, the ARDL estimates found a quadratic condition for both the GDP and FD squared series. To confirm those sufficient conditions, the SLM statistical and graphical illustrations will clearly perform the quadratic conditions. The SLM statistics equals to 11.560 and the null hypothesis of no U-shape condition at $1 \%$ significant level is rejected. While the FD squared gave us an inverted U-shape condition, the SLM statistics were not able to reject the null hypothesis. Table 15 that follows indicates the SLM estimates, while Figure 4 and 5 illustrate the U-shape and inverted U-shape conditions.

Table 15. Estimates of SLM U-shape test

\begin{tabular}{|l|c|c|}
\hline \multirow{2}{*}{} & \multicolumn{2}{|c|}{ Dependent variable: Tax } \\
\cline { 2 - 3 } & $G D P^{2}$ effect & $F D^{2}$ effect \\
\hline$G D P_{\min }$ & $7.232^{\star}[18.915]$ & - \\
\hline$F D_{\min }$ & - & $-1.989[-1.401]$ \\
\hline Slope at $G D P_{\min }$ & 3.338 & -1.913 \\
\hline Slope at $F D_{\min }$ & - & - \\
\hline$G D P_{\max }$ & $8.822^{\star}[11.563]$ & $0.557^{\star}[2.541]$ \\
\hline$F D_{\max }$ & - & - \\
\hline Slope at $G D P_{\max }$ & 1.877 & 2.854 \\
\hline Slope at $F D_{\max }$ & - & $1.400[0.084]$ \\
\hline SLM U-shape test & $11.560^{\star}[0.000]$ & {$[-20.142 ;-0.460]$} \\
\hline Extream point & {$[9.987 ; 13.199]$} & Inverted U-shape \\
\hline Decision & U-shape & \\
\hline
\end{tabular}

Note: $\left({ }^{*}\right)$ and $\left({ }^{*}\right)$ denotes significant at $1 \%$ and $5 \%$ levels, respectively. t-values.

\section{Conclusions}

The results of this study failed to show any significant impact of financial development on tax collection for Malaysia and this might be due to a few abrupt slowdowns of domestic and global economic growth that took place during the whole study period. There were a few policy reforms throughout the study period to enhance the effectiveness and efficiency of the tax collection system, including the change of tax rates imposed on individuals and 
companies to reduce the taxpayer burden. The major changes that took place include the decision to implement the Self-Assessment System (SAS) which took place from the years of assessment 2001 and 2004 for company and individual taxpayers respectively. To finance development projects, Malaysia must devise and implement tax strategies to increase its domestic tax revenue, for example, by improving the country's tax administration to reach hard-to-tax citizens. In order to diversify and increase revenues, some regulatory changes were made by the Inland Revenue Board (IRB), such as introducing the online service of eFiling in 2006, the amendment of the Tax Audit Framework in 2009, the adjustment of the Petroleum Income Tax (PITA) and the Real Property Gains Tax (RPGT) in 2010, as well as the increment of the service tax and levy on foreign workers in 2011. These implementations have helped to increase the efficiency and effectiveness of tax revenue collection. We have found that the implementation of GST collection on 1 April 2015 has improved the overall

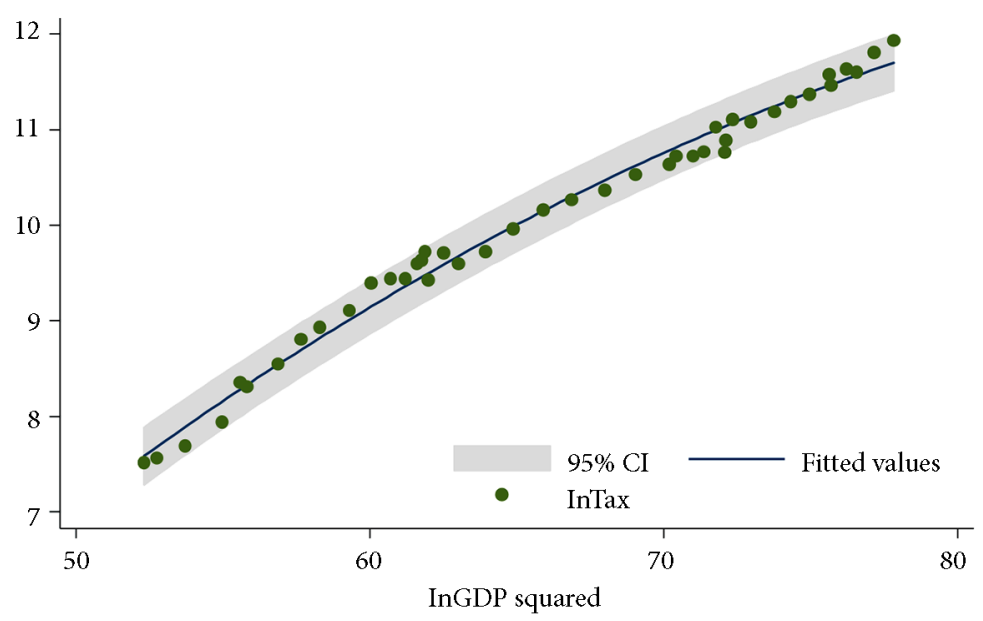

Figure 4. U-shaped relations between Tax and GDP

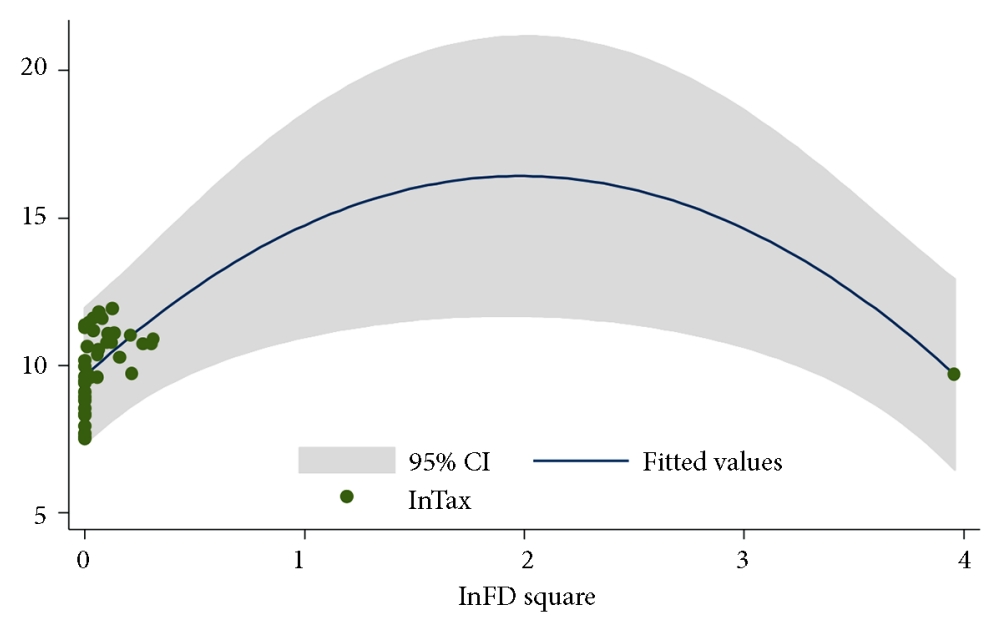

Figure 5. Inverted U-shaped relations between Tax and FD 
tax collection for Malaysia. For example, the government earned USD6 billion of GST collection in 2015 and this contributed $12.14 \%$ of the overall national tax revenue (Ministry of Finance Malaysia, 2016). In order to promote economic growth, the government should improve the liquidity and the size of financial activities in future. This can be done by removing regulatory and legislative barriers such as high tax rates, which will also increase capital flows with minimal constrain of financial development. With these barriers removed, the financial markets will see more integrated financial flow and permit greater risk diversification and lower capital costs.

\section{Acknowledgements}

This research is funded by the Ministry Higher Education of Malaysia under the Fundamental Research Grant Scheme (FRGS/1/2017/SS08/UTM/02/5). We also would like to thank the reviewer for their helpful comments to improve this article.

\section{References}

Abdullah, S., \& Morley, B. (2014). Environmental taxes and economic growth: evidence from panel causality tests. Energy Economics, 42, 27-33. https://doi.org/10.1016/j.eneco.2013.11.013

Adeniyi, O., Oyinlola, A., Omisakin, O., \& Egwaikhide, F. O. (2015). Financial development and economic growth in Nigeria: evidence from threshold modelling. Economic Analysis and Policy, 47, 11-21. https://doi.org/10.1016/j.eap.2015.06.003

Adkisson, R. V., \& Mohammed, M. (2014). Tax structure and state economic growth during the great recession. The Social Science Journal, 51, 79-89. https://doi.org/10.1016/j.soscij.2013.10.009

Adu, G., Marbuah, G., \& Mensah, J. T. (2013). Financial development and economic growth in Ghana: does the measure of financial development matter? Review of Development Finance, 3, 192-203. https://doi.org/10.1016/j.rdf.2013.11.001

Agbloyor, E. K., Abor, J. Y., Adjasi, C. K. D., \& Yawson, A. (2014). Private capital flows and economic growth in Africa: the role of domestic financial markets. Journal of International Financial Markets, Institutions and Money, 30, 137-152. https://doi.org/10.1016/j.intfin.2014.02.003

Aghion, P., Akcigit, U., Cagé, J., \& Kerr, W. R. (2016). Taxation, corruption, and growth. European Economic Review, 86, 24-51. https://doi.org/10.1016/j.euroecorev.2016.01.012

Aizenman, J., \& Pasricha, G. K. (2013). Why do emerging markets liberalize capital outflow controls? Fiscal versus net capital flow concerns. Journal of International Money and Finance, 39, 28-64. https://doi.org/10.1016/j.jimonfin.2013.06.018

Anwar, S., \& Sun, S. (2011). Financial development, foreign investment and economic growth in Malaysia. Journal of Asian Economics, 22, 335-342. https://doi.org/10.1016/j.asieco.2011.04.001

Ariff, M., \& Abu Bakar, S. Y. (1999). The Malaysian financial crisis: economic impact and recovery prospects. The Developing Economies, 37, 417-438. https://doi.org/10.1111/j.1746-1049.1999.tb00241.x

Barro, R. J., \& Sala-I-Martin, X. (1992). Public finance in models of economic growth. Review of Economic Studies, 59, 645-661. https://doi.org/10.2307/2297991

Bhattacharyya, S., \& Holder, R. (2014). Do natural resource revenues hinder financial development? The role of political institutions. World Development, 57(1), 101-113.

https://doi.org/10.1016/j.worlddev.2013.12.003 
Blackburn, K., Bose, N., \& Capasso, S. (2012). Tax evasion, the underground economy and financial development. Journal of Economic Behavior and Organization, 83, 243-253. https://doi.org/10.1016/j.jebo.2012.05.019

Bodman, P., Campbell, H., \& Le, T. (2012). Public investment, taxation and long-run output in economies with multi-level governments. Economic Modelling, 19, 1603-1611. https://doi.org/10.1016/j.econmod.2012.05.002

Brock, W. A., Sheinkman, J. A., Dechert, W. D., \& LeBaron, B. (1996). A test for independence base on the correlation dimension. Econometric Reviews, 15, 197-235. https://doi.org/10.1080/07474939608800353

Bujang, I., Abu Hakim, T., \& Ahmad, I. (2013). Tax structure and economic indicators in developing and high income OECD countries: panel cointegration analysis. Procedia Economics and Finance, 7, 164-173. https://doi.org/10.1016/S2212-5671(13)00231-1

Cavallari, L., \& Romano, R. (2017). Fiscal policy in Europe: the importance of making it predictable. Economic Modelling, 60, 81-97. https://doi.org/10.1016/j.econmod.2016.09.008

Chen, K. C., Wu, L., \& Wen, J. (2013). The relationship between finance and growth in China. Global Finance Journal, 24, 1-12. https://doi.org/10.1016/j.gf.2013.03.006

Dergiades, T., Martinopoulos, G., \& Tsoulfidis, L. (2013). Energy consumption and economic growth: parametric and non-parametric causality testing for the case of Greece. Energy Economics, 36, 686697. https://doi.org/10.1016/j.eneco.2012.11.017

Diks, C., \& Panchenko, V. (2006). A new statistic and practical guidelines for nonparametric Granger causality testing. Journal of Economic Dynamics and Control, 30, 1647-1669. https://doi.org/10.1016/j.jedc.2005.08.008

Feenberg, D. R., \& Rosen, H. S. (1987). Tax structure and public sector growth. Journal of Public Economics, 32, 185-201. https://doi.org/10.1016/0047-2727(87)90011-9

Futagami, K., Morita, Y., \& Shibata, A. (1993). Dynamic analysis of an endogenous growth model with public capital. Scandinavian Journal of Economics, 95, 607-625. https://doi.org/10.2307/3440914

Goulas, E., \& Zervoyianni, A. (2013). Growth, deficits and uncertainty: theoretical aspects and empirical evidence from a panel of 27 countries. The Quarterly Review of Economics and Finance, 53, 380-392. https://doi.org/10.1016/j.qref.2013.07.005

Granger, C. W. J. (1969). Investigating causal relations by econometric models and cross spectral methods. Econometrica, 37, 424-438. https://doi.org/10.2307/1912791

Hatfield, J. W. (2015). Federalism, taxation, and economic growth. Journal of Urban Economics, 87, 114-125. https://doi.org/10.1016/j.jue.2015.01.003

Herfindahl, O. C. (1957). Tax policy for stability and growth. The American Economic Review, 47, 139-144.

Herwartz, H., \& Walle, Y. M. (2014). Determinants of the link between financial and economic development: evidence from a functional coefficient model. Economic Modeling, 37, 417-427. https://doi.org/10.1016/j.econmod.2013.11.029

Ho, W. H., \& Yang, C. C. (2013). Factor income taxation and growth with increasing integration of world capital markets. Economic Letters, 120, 477-480. https://doi.org/10.1016/j.econlet.2013.05.024

Hove, S., Tchana, F. T., \& Mama. A. T. (2017). Do monetary, fiscal and financial institutions really matter for inflation targeting in emerging market economies? Research in International Business and Finance, 39, 128-149. https://doi.org/10.1016/j.ribaf.2016.07.025

Hsueh, S. J., Hu, Y. H.; \& Tu, C. H. (2013). Economic growth and financial development in Asian countries: a bootstrap panel Granger causality analysis. Economic Modeling, 32, 394-301.

https://doi.org/10.1016/j.econmod.2013.02.027 
Hye, Q. M. A., \& Islam, F. (2012). Does financial development hampers economic growth: empirical evidence from Bangladesh. Journal of Business Economics and Management, 14, 558-582.

Jinjarak, Y. (2013). Economic integration and government revenue from financial repression. Economic Systems, 37, 271-283. https://doi.org/10.1016/j.ecosys.2012.10.003

Kneller, R., Bleaney, M. F., \& Gemmell, N. (1999). Fiscal policy and growth: evidence from OECD countries. Journal of Public Economics, 74, 171-190. https://doi.org/10.1016/S0047-2727(99)00022-5

Kumar, S. (2017). New evidence on stock market reaction to dividend announcements in India. Research in International Business and Finance, 39, 327-337. https://doi.org/10.1016/j.ribaf.2016.09.009

Lee, Y., \& Gordon, R. H. (2005). Tax structure and economic growth. Journal of Public Economics, 89, 1027-1043. https://doi.org/10.1016/j.jpubeco.2004.07.002

Levine, R. (1991). Stock markets, growth and tax policy. The Journal of Finance, 46, 1445-1465. https://doi.org/10.1111/j.1540-6261.1991.tb04625.x

Li, J. F., \& Lin, Z. X. (2015). The impact of sales tax on economic growth in the United States: an ARDL bounds testing approach. Applied Economics Letter, 22(15), 1262-1266. https://doi.org/10.1080/13504851.2015.1023933

Lind, J. T., \& Mehlum, H, (2010). With or without U? The appropriate for a U-shaped relationship. Oxford Bulletin of Economics and Statistics, 72(1), 109-118.

https://doi.org/10.1111/j.1468-0084.2009.00569.x

Loganathan, N., Taha, R., Ahmad, N., \& Subramaniam, T. (2017). Taxation, growth and the stock traded nexus in emerging Asian countries: heterogeneous and semi-parametric panel estimates. Economic Research-Ekonomska istraživanja, 30(1), 566-580. https://doi.org/10.1080/1331677X.2017.1305789

Madsen, J. B., \& Ang, J. B. (2016). Finance-led growth in the OECD since the nineteenth century: how does financial development transmit to growth? Review of Economics and Statistics, 98, 552-572. https://doi.org/10.1162/REST_a_00513

Menyah, K., Nazlioglu, S., \& Worlde-Rufael, Y. (2014). Financial development, trade openness and economic growth in African countries: new insights from a panel causality approach. Economic Modelling, 37, 386-394. https://doi.org/10.1016/j.econmod.2013.11.044

Ministry of Finance Malaysia (2016). Economic Report 2015/2016. Retrieved from http://www.treasury. gov.my/

Narayan, P. K., \& Narayan, S. (2013). The short-run relationship between the financial system and economic growth: new evidence from regional panels. International Review of Financial Analysis, 29, 70-78. https://doi.org/10.1016/j.irfa.2013.03.012

Ngare, E., Nyamongo, E. M., \& Misati, R. N. (2014). Stock market development and economic growth in Africa. Journal of Economic and Business, 74, 24-39. https://doi.org/10.1016/j.jeconbus.2014.03.002

Ojede, A., \& Yamarik, S. (2012). Tax policy and state economic growth: the long-run and short-run of it. Economics Letters, 116, 161-165. https://doi.org/10.1016/j.econlet.2012.02.023

Oskooe, S. A. P. (2010). Emerging stock market performance and economic growth. American Journal of Applied Sciences, 7, 265-269. https://doi.org/10.3844/ajassp.2010.265.269

Pesaran, M., Shin, Y., \& Smith, R. (2001). Bound testing approaches to the analysis of level relationship. Journal of Applied Economics, 16, 289-326. https://doi.org/10.1002/jae.616

Peter, V. M., \& Ker, I. A. (2001). The influence of tax mix and tax policy on savings and capital formation in developing economies: a survey. Asia-Pacific Development Journal, 8(1), 13-40.

Radu, D. I. (2012). Tax havens impact on the world economy. Social and Behavioral Sciences, 62, 398402. https://doi.org/10.1016/j.sbspro.2012.09.064

Romero-Ávila, D., \& Strauch, R. (2008). Public finances and long-term growth in Europe: evidence from a panel data analysis. European Journal of Political Economy, 24, 172-191.

https://doi.org/10.1016/j.ejpoleco.2007.06.008 
Schandlbauer, A. (2016). How do financial institutions react to a tax increase? Journal Financial Intermediation, 1-21.

Soli, V. O., Harvey, S. K., \& Hagan, E. (2008). Fiscal policy, private investment and economic growth: the case of Ghana. Studies in Economics and Finance, 25, 112-130. https://doi.org/10.1108/10867370810879438

Stoilova, D. (2017). Tax structure and economic growth: Evidence from the European Union. Contaduría y Administración, 62(3), 1041-1057. https://doi.org/10.1016/j.cya.2017.04.006

Tagkalakis, A. (2011). Asset price volatility and government revenue. Economic Modelling, 28, 25322543. https://doi.org/10.1016/j.econmod.2011.07.015

Taha, R., Colombage, S. R. N., Maslyuk, S., \& Loganathan, N. (2013). Does financial system activity affect tax revenue in Malaysia? Bounds testing and causality approach. Journal of Asian Economics, 24, 147-157. https://doi.org/10.1016/j.asieco.2012.11.001

Thumrongvit, P., Kim, Y., \& Pyun, C.S. (2013). Linking the missing market: the effect of bond markets on economic growth. International Review of Economics and Finance, 27, 529-541. https://doi.org/10.1016/j.iref.2013.01.008

Toda, H. Y., \& Yamamoto, T. (1995). Statistical inference in vector autoregressions with possibly integrated processes. Journal of Econometrics, 66, 225-250. https://doi.org/10.1016/0304-4076(94)01616-8

Uddin, G. S., Sjö, B., \& Shahbaz, M. (2013). The causal nexus between financial development and economic growth in Kenya. Economic Modelling, 35, 701-707. https://doi.org/10.1016/j.econmod.2013.08.031

Widmalm, F. (2001). Tax structure and growth: are some taxes better than others? Public Choice, 107, 199-219. https://doi.org/10.1023/A:1010340017288

World Bank. (2015). World development indicators. The World Bank: Washington D.C.

Yilmaz, E. (2013). Competition, taxation and economic growth. Economic Modelling, 35, 134-139. https://doi.org/10.1016/j.econmod.2013.06.040

Zhang, L., Ru, Y., \& Li, J. (2016). Optimal tax structure and public expenditure composition in a simple model of endogenous growth. Economic Modelling, 59, 352-360.

https://doi.org/10.1016/j.econmod.2016.08.005

Zhang, L., \& Berzemer, B. (2016). Finance and growth in China, 1995-2013. More liquidity or more development? Cambridge Journal of Regions, Economy and Society, 9(3), 613-631. https://doi.org/10.1093/cjres/rsw022

Zimmermannova, J., Skalickova, J., \& Siroky, J. (2016). what can tax revenues tell us about the economic activity of regions? Economics and Sociology, 9(1), 114-128. https://doi.org/10.14254/2071-789X.2016/9-1/8

Zivot, E., \& Andrews, D. (1992). Further evidence on the great crash, the oil price shock and the unit root hypothesis. Journal of Business Economics Statistics, 10, 251-270. 